AperTO - Archivio Istituzionale Open Access dell'Università di Torino

\title{
Genotyping at the CSN1S1 locus by PCR-RFLP and AS-PCR in a Neapolitan Goat Population
}

\section{This is the author's manuscript}

Original Citation:

Availability:

This version is available http://hdl.handle.net/2318/1507128

since 2018-03-17T22:43:02Z

Published version:

DOI:10.1016/j.smallrumres.2007.03.010

Terms of use:

Open Access

Anyone can freely access the full text of works made available as "Open Access". Works made available under a Creative Commons license can be used according to the terms and conditions of said license. Use of all other works requires consent of the right holder (author or publisher) if not exempted from copyright protection by the applicable law. 


\section{IIIS AperTO}

UNIVERSITÀ

DEGLI STUDI

DI TORINO

This is the author's final version of the contribution published as:

Cosenza G., A. Pauciullo, D. Gallo, L. Colimoro, A. D’Avino, Mancusi, L. Ramunno. Genotyping at the CSN1S1 locus by PCR-RFLP and AS-PCR in a Neapolitan goat population. Small Ruminant Research, 74 (1-3), 2008, 84-90

DOI:10.1016/j.smallrumres.2007.03.010

The publisher's version is available at:

https://www.sciencedirect.com/science/article/pii/S0921448807000995

When citing, please refer to the published version.

\section{Link to this full text:}

https://ac.els-cdn.com/S0921448807000995/1-s2.0-S0921448807000995-

main.pdf? tid=dd33b996-baaf-4f88-bedc-

9c5b05b6f309\&acdnat=1521322866 9a14c679c8916dec9c8059e08766507a

This full text was downloaded from iris-Aperto: https://iris.unito.it/

\section{iris-AperTO}


1 Genotyping at the CSN1S1 locus by PCR-RFLP and AS-PCR in a Neapolitan

2 goat population

3

4 Cosenza G., A. Pauciullo, D. Gallo, L. Colimoro, A. D’Avino, Mancusi, L. Ramunno* 5

6 Dipartimento di Scienze del Suolo, della Pianta, dell 'Ambiente e delle Produzioni Animali,

7 Università degli Studi di Napoli "Federico II", Napoli, Italy

8

9

10

$11 *$ Corresponding author.

$12 \quad$ Tel.: +39 0812539004;

13 fax: +39 0817762886 .

14 E-mail address: ramunno@unina.it

15

16

17

18

19

20

21

22 


\section{Abstract}

2 The goat CSN1S1 gene has for many years been an excellent model for demonstrating

3 that most of the variability observed in the as1-casein content in goat's milk is due to the

4 presence of autosomal alleles at a single structural locus. Until now, about 17 alleles

5 associated to at least four levels of as1-casein expression in milk have been described at

6 the CSN1S1 locus in the domestic goat (Capra hircus). The great importance of goat as1-

7 casein polymorphism is due to its qualitative as well as quantitative implications. In the

8 present work five PCR protocols (PCR-RFLPs, AS-PCR) were set up for rapid

9 genotyping of B1, B2*, B3, B4 and C CSN1S1 alleles, until now detectable only by milk

10 electrophoresis. Application of these protocols, together with previously described

11 methods to identify CSN1S1 01, E, M, F, N and A* (CSN1S1 A, G, I, H) alleles, allow us to

12 define, at DNA level, the genetic structure of the autochthonous goat reared in the province

13 of Naples for the highest number of possible alleles at this locus. Monitoring of CSN1S1

14 variability in the Neapolitan goat population indicates a high frequency of low $(\mathrm{F}, 0.368)$

15 and null (N, 0.227) alleles.

17 Keywords: Goat; CSN1S1; Alleles; PCR-RFLP; AS-PCR 


\section{1. Introduction}

2 Among Ca-sensitive caseins (as1, $\mathrm{p}$ and as2), the as1 fraction is without doubt the most

3 extensively inves- tigated in goat. Such protein is codified by a single autosomal gene

4 (CSN1S1) mapped on chromosome 6 and clustered with genes of the other casein fractions

5 (CSNIS2, CSN2 and CSN3 for as2, p and k, respec- tively) in a DNA stretch of about 250

$6 \mathrm{~kb}$ (Leroux and Martin, 1996; Rijnkels, 2002).

7 So far, at least 16 alleles have been identified, which are associated with different levels

8 of as1-casein expres- sion in the milk. A first group of alleles (A, B1, B2, B3, B4, C, H,

$9 \mathrm{~L}, \mathrm{M}$ ) are related to a normal content of as 1-casein (about $3.5 \mathrm{~g} / \mathrm{l}$ ), whereas alleles I and

10 E are associated to an intermediate content (about $1.1 \mathrm{~g} / \mathrm{l}$ ), and alleles $\mathrm{F}$ and $\mathrm{G}$ are related

11 to a low level of as1-casein in the milk (about $0.45 \mathrm{~g} / 1$ ). Alleles CSN1S1 N, 01 and 02 are

12 'null' alleles and have been associated with the appar- ent lack of as1-casein in milk

13 (Chianese et al., 1997; Martin et al., 1999; Bevilacqua et al., 2002; Ramunno et al., 2005).

14 Most of the mutational events responsible for the formation of such alleles have already

15 been identi- fied. The B1 allele is the original one from which two divergent lineages of

16 alleles originate: A-type (A, 01, 02, I, G, H) and B-type (B2, B3, B4, C, E, F, L) alleles

17 (Chianese et al., 1997; Grosclaude and Martin, 1997). It has been hypothesized that the

18 CSNIS1 $\mathrm{N}$ and $\mathrm{M}$ alleles could be originated by an interallelic recombination event

19 between A- and B-type alleles (Bevilacqua et al., 2002; Ramunno et al., 2005). In par-

20 ticular, the alleles associated to a normal content of this casein fraction originated from

21 single nucleotide substitutions responsible for aminoacid substitutions (Chianese et al.,

22 1997; Martin et al., 1999; Bevilacqua et al., 2002). While the molecular event

23 characteriz- ing the I allele is unknown (Chianese et al., 1997), the $\mathrm{E}$ allele is characterized 
1 by insertion of a DNA seg- ment (LINE, Long Interspersed Nuclear Element, 457

2 nucleotides long) which took place within the 19th exon (Jansà Pérez et al., 1994). For

3 the $G$ allele the muta- tional event is a transition $\left(\begin{array}{ll}G & A\end{array}\right)$ occurring in the $5 \mathrm{j}_{\text {-splice }}$

4 site consensus sequence responsible of an alternatively spliced mRNA characterized by the

5 out-splicing of exon 4 (Brignon et al., 1990; Martin and Leroux, 1994).

6 The $\mathrm{F}$ allele is, instead, characterized by a dele- tion of the 23rd nucleotide of the 9th

7 exon (Leroux et al., 1992). Cytosine deletion results in a one-nucleotide frameshift and

8 determines a premature stop codon in exon 12 (Leroux et al., 1992; Ramunno et al., 2005).

9 By means of Northern blot analysis the amount of as1 casein mRNA transcribed from the F

10 allele was estimated to be at least six times lower than the transcribed one from the A allele

11 (Leroux et al., 1992). Furthermore, the F allele was shown to yield multiple alternatively

12 spliced transcripts, of which the most representative mRNA pop- ulation is characterized by

13 the alternative skipping of exons $9-11$ and is responsible as a consequence, for the

14 synthesis of a form of as 1 casein deprived of 37 aa (Leroux et al., 1992; Ramunno et al.,

15 2005). Sequence data and typing results show that the CSN1S1 N allele is characterized,

16 like the CSN1S1 F allele, by the same exonic mutation. The amount of mRNA transcribed

17 by the CSN1S1 $\mathrm{N}$ allele is apparently one-third of that tran- scribed by the CSN1S1 F allele

18 and, similar to this one, alternatively spliced transcripts are produced (Ramunno et al.,

19 2005). It has been suggested that a mutation, occur- ring at $1319 \mathrm{nt}$ of the promoter region,

20 creates an extra putative activator protein (AP-1) binding motif in the sequence of the F

21 allele, which can be responsible for the different expression of alleles $\mathrm{F}$ and $\mathrm{N}$ (Ramunno

22 et al., 2005).

23 The 01 allele, the true null allele, is characterized by the deletion of a DNA segment of 
1 about $8.5 \mathrm{~kb}$ starting from the 181 st nucleotide of the intron 12 , and including the last 7

2 exons of the gene (Cosenza et al., 2003), while a large insertion, so far uncharacterized, is

3 the mutational event responsible for the 02 allele (Martin et al., 1999). Furthermore, recent

4 analysis of the CSN1S1 gene promoter showed a transition G A in position 1623.

5 This mutation, besides characterizing the $\mathrm{N}$ allele, would also characterize the 01 allele,

6 being polymorphic for the A allele. The latter result would suggest the existence of a second

7 A allele (called A2) from which the two null alle- les would originate (Ramunno et al., 8 2005), supporting the idea that alleles 01 and 02 derive from two different $A$ subtypes

9 (Grosclaude and Martin, 1997).

10 While the CSN1S1 A and $\mathrm{B}^{*}\left(\mathrm{~B}^{*}=\mathrm{B} 1, \mathrm{~B} 2, \mathrm{~B} 3, \mathrm{~B} 4, \mathrm{C}\right)$ alleles appear more frequently in

11 the autochthonous goat population of southern Italy, alleles E and F are more frequent in

12 French, Swiss and Spanish breeds (Ramunno et al., 1994; Jordana et al., 1996; Enne et al.,

13 1997; Grosclaude and Martin, 1997; Caroli et al., 2006).

14 The aim of the present study is to establish the genetic structure at CSN1S1 locus of the

15 Neapolitan goat and to set up methods for the identification of CSN1S1 B1, B2 B3, B4,

$16 \mathrm{C}$ alleles by using PCR-RFLP (PCR-restriction fragment polymorphism) and AS-PCR

17 (allele specific- PCR).

19 2. Materials and methods

20 2.1. DNA samples

21 The research was carried out on 285 individual DNA sam- ples of local Neapolitan goats

22 reared on different farms in the Sorrento Peninsula (southern Italy). Such population is

23 the result of the crossbreed of goat Neapolitan mainly with Saanen, Malta and Alpine 
1 goats. The main attitude of the Neapoli- tan goat is the kids and milk production

2 (approximately 4501 for lactation) (Ciotola and Peretti, 2004). Genomic DNA was 3 extracted from blood leukocytes according to the method of Goossens and Kan (1981).

5 2.2. Genotyping at goat CSN1S1 locus by PCR based methods

7 Alleles CSN1S1 M, E and F, N and 01 were detected by means of ACRS-PCR (amplified 8 created restriction site-PCR) (Bevilacqua et al., 2002), PCR (Jansà Pérez et al., 1994), 9 XmnI PCR-RFLP (Ramunno et al., 2000) and AS-PCR (Cosenza et al., 2003), 10 respectively. Furthermore, based on the nucleotide sequence data, the PCR-RFLP 11 procedure developed for geno- typing of CSN1S1 F and $\mathrm{N}$ alleles using XmnI allows the 12 CSN1S1 A* allele (CSN1S1 A, G, I, H) to be discriminated (Ramunno et al., 2000).

13 In order to identify the goat carriers of CSN1S1 C, B3, B2* (CSN1S1 B2, L) and B1 14 alleles, genotyping methods based on PCR-RFLP were developed, whereas AS-PCR 15 was set up to detect the carriers of CSN1S1 B4 allele. Primer sequences and the thermal 16 amplification conditions are reported in Tables 1 and 2, respectively. PCR was carried 17 out by using Gene Amp PCR System 2400 (Perkin-Elmer). The CSN1S1 A, G, I, H 18 and CSN1S1 B2 and L alleles were gathered in CSN1S1 A* and CSN1S1 B2* groups, 19 respectively, since they are indistinguishable with the methods developed in this study. 20 The $25 \mu \mathrm{l}$ reaction mix for each PCR product comprised: $100 \mathrm{ng}$ of genomic DNA, 50

$21 \mathrm{mM} \mathrm{KCl}, 10 \mathrm{mM}$ Tris- $\mathrm{HCl}(\mathrm{pH} 9.0), 0.1 \%$ Triton $\mathrm{X}-100,3 \mathrm{mM} \mathrm{MgCl}_{2}, 5 \mathrm{pmol}$ of each 22 primer, dNTPs each at $400 \mu \mathrm{M}, 2.5 \mathrm{U}$ of Taq DNA Polymerase (Promega, Madison, WI), 23 and $0.04 \%$ BSA. Digestion of $17 \mu$ l of each PCR amplification was accomplished with 
$1 \quad 10 \mathrm{U}$ of the specific endonuclease for $5 \mathrm{~h}$ at $37^{\circ} \mathrm{C}$ following the supplier's directions for

2 buffer conditions. PCR and digestion products were analysed directly by electrophoresis

3 in 1.5\% TBE agarose gel (Bio-Rad) in IX TBE buffer and stained with ethidium

4 bromide.

\section{Results and discussion}

7 The $\mathrm{G}>\mathrm{C}$ transversion at the 22nd nucleotide of exon 10 which differentiates CSNISI B1

8 allele from A-type (A, 01, 02, I, G, H) alleles (Table 3) is responsible for the creation of

9 the $M n l$ I restriction site ( NNNNNNNGAGG). Consequently, the ampli- fied fragments

10 relative to the CSN1S1B1 and CSN1S1 "non-B1" alleles are characterized by the presence

11 and absence, respectively, of the restriction site. Therefore, by means of $M n l I$ digestion of

12 PCR products, includ- ing the 10th exon and part of the 11th exon of the goat CSNIS1

13 gene, CSN1S1 "non-B1" homozygous indi- viduals show a single undigested fragment of

$14311 \mathrm{bp}$, whereas CSN1S1 B1 homozygous individuals have two fragments of 125 and 186

15 bp (Fig. 1).

16 By contrast, a restriction site of the same endonuclease (CCTCNNNNNNNN) is altered

17 by the $\mathrm{T}>\mathrm{C}$ transversion occurring at the eighth nucleotide of exon 4 from which the

18 CSN1S1 B2 allele originated (Table 3). Therefore, digestion with this endonuclease of the

19 ampli- fied DNA fragment (310 bp), contained this exon and flanking region, shows a

20 single undigested fragment for the CSNIS1 B2 allele and two fragments of 77 and $233 \mathrm{bp}$

21 for "non-B2" alleles (Fig. 1).

22 The CSN1S1 B3 allele derives from the B2 allele as a consequence of a G>A transition

23 occurring at the 14th nucleotide of exon 12 (Table 3). This mutation removes a DdeI 
1 endonuclease restriction site (CTNAG). DdeI digestion of a PCR product of $231 \mathrm{bp}$

2 spanning the 12th exon and flanking regions, would allow carriers for the presence of

3 adenine to be identified. As a consequence, the PCR product, uncut in the presence of

4 guanine, is now restricted to two fragments of 97 and $134 \mathrm{bp}$ (Fig. 1).

5 However, the mutation which discriminates allele B4 from B3 (a nucleotide substitution

$6 \quad A>G$ at the 139th nt of exon 17) (Table 3) does not alter or create any restriction site.

7 Hence, a method based on allele-specific PCR (AS-PCR) was developed in order to 8 distinguish the carriers of the CSN1S1 B4 allele. Using specific primers for AS-PCR, 9 the obtained amplicon length is $391 \mathrm{bp}$ and it includes part of exon 17 and the next intron.

10 The two allele-specific forward primers differ in the last nucleotide at 3 '-end $(A>G)$.

11 Thus, for the CSN1S1 4 homozygote samples, PCR amplification is successful only using

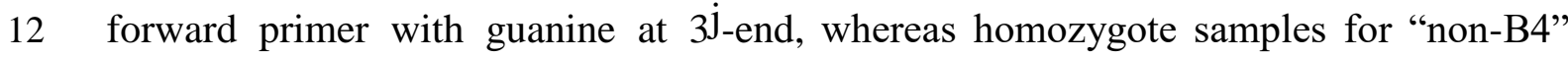

13 alleles are successfully amplified only by forward primer with adenine at 3'-end. The

14 heterozygote samples are effectively amplified with both forward primers (Fig. 2).

15 Finally, the mutation characterizing the CSN1S1 C allele (double nucleotide substitution,

$16 \mathrm{CA} \rightarrow \mathrm{AT}$, occurring between the 16th and 17th nt of exon 3) (Table 3) alters the restriction

17 site of $H p h 1$ endonuclease (NNNNNNNTCACC). As shown in Fig. 2, the amplified

18 fragments relative to the CSN1S1 C and CSN1S1 "non-C" alleles are characterized by the 19 absence and presence, respectively, of the restriction site. Therefore, by means of PCR20 RFLP, CSN1S1 "non-C" homozygous individuals show two fragments of 83 and $111 \mathrm{bp}$, 21 whereas CSN1S1 C homozygous individuals show a single undigested fragment of $194 \mathrm{bp}$.

22 The typing of B-type alleles (CSN1S1 B1, B2*, B3, B4, C) was carried out going 
1 backwards from alleles B1 to C along the phylogenetic tree (Fig. 3). This is was necessary

2 since these alleles originated one by one in successive mutations.

3 The results of B-type allele genotyping (CSN1S1 B1, B2*, B3, B4, C) by means of the 4 set up protocols confirmed the origin of each allele as reported in the phylogenetic tree 5 (Fig. 3).

6 Genotyping the whole population did not show car- riers of CSN1S1 M and 01 allele, and 7 allowed the observation of 26 out of 45 possible genotypes with 9 alleles present in the 8 investigated population. The dis- tribution of the observed genotypes and the frequency of

9 alleles at CSNIS1 locus are reported in Table 4. In particular, among the strong alleles of

10 the B-type group (total frequency, 0.18), our research evidenced a higher frequency of B3

11 (0.072) and B4 (0.085) alleles. In com- parison to the other local populations reared in the 12 rest of southern Italy, local Neapolitan goats are characterized by a high frequency of low

13 (F, 0.368) and null (N, 0.227) alleles, which makes this population similar to goats of 14 French origin (Ramunno et al., 1994). This character- istic may well be correlated to 15 strong genetic erosion phenomena of the original population, as a consequence of 16 crossbreeds with breeding stock belonging to Saanen, Maltese and Alpine breeds (Ciotola 17 and Peretti, 2004).

19 4. Conclusion

20 Actually, the known goat CSN1S1 alleles are associ- ated with different expression levels

21 (Chianese et al., 1997; Martin et al., 1999; Bevilacqua et al., 2002; Ramunno et al., 22 2005). It has been hypothesized that the observed differences in the expression of the 23 goat CSN1S1 gene could be the direct consequence of more elaborated systems of gene 
1 regulation (Ramunno et al., 2005). Indeed, comparative analysis of the CSN1S1 (A, F

2 and $\mathrm{N}$ alleles) gene promoters evidenced a $\mathrm{G} A$ transition in position 1319 which seems

3 to create an extra putative activator protein (AP-1) binding motif in the sequence of the

4 F allele at a short distance from a constitutive link site of the same factor. The AP-1

5 transcriptional complexes are known to be important third messengers for target genes

6 regulated by extra- cellular mediators; therefore it was considered possible that the goat

7 CSN1S1 gene would be responsive to AP-1 (Angel and Karin, 1991; Kerppola and

8 Curran, 1993). A preliminary investigation upon goats with different known genotypes

9 at the CSN1S1 locus and belonging to different breeds/genetic types, showed that the G

10 A substitution in 1319 position is present not only in the $\mathrm{F}$ allele but also in the remaining

11 B-type alleles (Ramunno, L., pers. commun.). This suggests that the transcriptional

12 activity of B-type alleles could be highlighted.

13 Until now CSN1S1 B1, B2, B3, B4 and C alleles were genotyped by using milk

14 electrophoresis as isoelectrofocusing (IEF). However, these methods are not useful for fast,

15 unambiguous typing of individuals. Therefore, by using methods developed in this study,

16 it is possible, both quickly and more accurately, to type animals independently of age, sex,

17 and lactation and, for example, perform quail-quantitative analyses of mRNA (by RTPCR

18 and real-time PCR) in order to evaluate the different expression level of the single alleles

19 and thus choose animals producing milk with particular chemical-physical and

20 technological characteristics.

\section{Acknowledgement}


1 This is contribution no. 140 from the Department of Soil, Plant, Environment and

2 Animal Production Sciences, Agriculture Faculty, University of Naples "Federico II".

4 References

5 Angel, P., Karin, M., 1991. The role of Jun, Fos and the AP-1 complex in cell6 proliferation and transformation. Biochim. Biophys. Acta 1072, 129-157.

8 Bevilacqua, C., Ferranti, P., Garro, G., Veltri, C., Lagonigro, R., Ler- oux, C., Pietrolà, E.,

9 Addeo, F., Pilla, F., Chianese, L., Martin, P., 2002. Interallelic recombination is probably

10 responsible for the occurrence of a new alpha(s1)-casein variant found in the goat species.

11 Eur. J. Biochem. 269 (4), 1293-1303.

13 Brignon, G., Mahé, M.F., Ribadeau Dumas, B., Mercier, J.C., Grosclaude, F., 1990.

14 Two of the three genetic variants of goat as1-casein which are synthesized at a reduced

15 level have an inter- nal deletion possibly due to altered RNA splicing. Eur. J. Biochem. 193, $16 \quad 237-241$.

18 Caroli, A., Chiatti, F., Chessa, S., Rignanese, D., Bolla, P., Pagnacco, G., 2006. Focusing

19 on the goat casein gene complex. J. Dairy Sci. 89 (8), 3178-3187.

21 Chianese, L., Ferranti, P., Garro, G., Mauriello, R., Addeo, F., 1997. Occurrence of three 22 novel alpha s1-casein variants in goat milk. Milk Protein Polymorphism FIL-IDF, 23 Palmerston North, New Zealand, pp. 259-267. 
2 Ciotola, F., Peretti, V., 2004. Razze zootecniche in pericolo di estinzione: la capra 3 napoletana. Vita Campagna 9, 48.

4

5 Cosenza, G., Illario, R., Rando, A., Di Gregorio, P., Masina, P., Ramunno, L., 2003.

6 Molecular characterization of the goat $C S N 1 S 1^{01}$ allele. J. Dairy Res. 70 (2), 237-240.

8 Enne, G., Feligini, M., Greppi, G.F., Iametti, S., Pagani, S., 1997. Gene frequencies of 9 caprine as1-casein polymorphism in dairy goats. In: IDF Seminar "Milk Protein 10 Polymorphism II", Palmerston North, pp. 275-279.

12 Goossens, M., Kan, Y.W., 1981. DNA analysis in the diagnosis of hemoglobin disorders.

13 Method Enzymol. 76, 805-817.

15 Grosclaude, F., Martin, P., 1997. Casein polymorphism in the goat. In: IDF Seminar "Milk

16 Protein Polymorphism II", Palmerston North, pp. 241-253.

18 Jansà Pérez, M.J., Leroux, C., Sanchez Bonastre, A., Martin, P., 1994. Occurrence of a

19 LINE sequence in the 3jUTR of the goat as1-casein E encoding allele associated with a 20 reduced protein synthesis level. Gene 147, 177-179.

22 Jordana, J., Amills, M., Diaz, E., Angulo, C., Serradilla, J.M., Sanchez, A., 1996. Gene

23 frequencies of caprine as1-casein polymorphism in Spanish goat breeds. Small Rumin. 
1 Res. 20, 215-221.

3 Kerppola, T.K., Curran, T., 1993. Selective DNA bending by a variety of bZIP proteins.

4 Mol. Cell. Biol. 13, 5479-5489.

5

6 Leroux, C., Martin, P., 1996. The caprine as1- and p-casein are 12-kb apart and 7 convergently transcribed. Anim. Genet. 27 (Suppl. 2), 93.

9 Leroux, C., Mazure, N., Martin, P., 1992. Mutations away from splice site recognition 10 sequences might cis-modulate alternative splicing of goat as1-casein transcripts.

11 Structural organization of the relevant gene. J. Biol. Chem. 267, 6147-6157.

13 Martin, P., Leroux, C., 1994. Characterization of a further as1-casein variant generated 14 by exon skipping. In: Proceedings of the 24th International Society of Animal Genetics 15 Conference, E43, Prague, p. 88 (Abstract).

17 Martin, P., Ollivier-Bousquet, M., Grosclaude, F., 1999. Genetic polymorphism of 18 caseins: a tool to investigate casein micelle orga- nization. Int. Dairy J. 9, 163-170.

20 Ramunno, L., Cosenza, G., Pappalardo, M., Pastore, N., Gallo, D., Di Gregorio, P.,

21 Masina, P., 2000. Identification of the goat CSN1S1F allele by means of PCR-RFLP

22 method. Anim. Genet. 31 (5), 342-343. 
1 Ramunno, L., Cosenza, G., Rando, A., Pauciullo, A., Illario, R., Gallo, D., Di Berardino,

2 D., Masina, P., 2005. Comparative analysis of gene sequence of goat CSN1S1 F and N

3 alleles and characterization of CSN1S1 transcript variants in mammary gland. Gene 345

4 (2), 289-299.

5

6 Ramunno, L., Rando, A., Di Gregorio, P., Capogreco, B., Masina, P., 1994. Indagine di

7 popolazione sui geni a effetto maggiore sul contenuto di caseina asl e p nel latte di capra.

8 Zoot. Nutr. Anim. 20, 107-111.

9

10 Rijnkels, M., 2002. Multispecies comparison of the casein gene loci and evolution of

11 casein gene family. J. Mammary Gland Biol. Neoplasia 7, 327-345.

12

13

14 
1 Table 1

2 Oligonucleotide primers, positions and restriction enzymes for PCR-RFLPs and AS-PCR

3

\begin{tabular}{|c|c|c|c|}
\hline CSN1S1 alleles & Position $\mathrm{nt}^{\mathrm{b}}$ & Primers sequence $\left(5^{\prime}-3^{\prime}\right)$ & Genotyping \\
\hline $\mathrm{C}$ & $\begin{array}{l}5048-5070 \\
\text { Complementary to: } 5222-5241\end{array}$ & $\begin{array}{l}\text { Forward: AACAGCACTGTTAAATGTATAAT } \\
\text { Reverse: TCATCAGTTAAGCTACACAA }\end{array}$ & $H p h \mathrm{I}^{a}$ \\
\hline B4 & $\begin{array}{l}\text { 16914-16931 } \\
\text { Complementary to: } 17287-17304\end{array}$ & $\begin{array}{l}\text { Forward: AGAACAGTGGAAAGACTG; AGAACAGTGGAAAGACTA } \\
\text { Reverse: CCCACACTGCATTCTAAT }\end{array}$ & $\begin{array}{l}\text { AS- } \\
\text { PCR }\end{array}$ \\
\hline B3 & $\begin{array}{l}12064-12084 \\
\text { Complementary to: } 12274-12294\end{array}$ & $\begin{array}{l}\text { Forward: TTAGTTTCCCATTCTTTACTC } \\
\text { Reverse: GAAGCTCTAACATGATTTGAT }\end{array}$ & $D d e \mathrm{I}^{\mathrm{a}}$ \\
\hline B2 & $\begin{array}{l}\text { 5995-6016 } \\
\text { Complementary to: } 6284-6304\end{array}$ & $\begin{array}{l}\text { Forward: TTCAAATGGAAAAACATTCTCC } \\
\text { Reverse: GTCAAATGTATAGGTACAGAT }\end{array}$ & $M n l I^{\mathrm{a}}$ \\
\hline B1 & $\begin{array}{l}\text { 10463-10483 } \\
\text { Complementary to: } 10752-10773\end{array}$ & $\begin{array}{l}\text { Forward: GAAAAGAGAACATGTACTTTG } \\
\text { Reverse: CATCTTCCTTTTGAATGTACTT }\end{array}$ & $M n l I^{\mathrm{a}}$ \\
\hline
\end{tabular}

4

5 a Restriction enzymes used for PCR-RFLP genotyping.

$6 \mathrm{~b}$ Numbering of primers agrees with the nucleotide sequence of the goat CSN1S1 gene

7 (EMBL Acc. No. AJ504710).

8 
1 Table 2

2 Thermal amplification programs for (a) PCR and (b) AS-PCR Cycle

3

\begin{tabular}{llll}
\hline Cycle & Denaturation & Annealing & Extension \\
\hline
\end{tabular}

(a) PCR

$\begin{array}{llll}1 & 97^{\circ} \mathrm{C}-2 \mathrm{~min} & 55^{\circ} \mathrm{C}-45 \mathrm{~s} & 72^{\circ} \mathrm{C}-45 \mathrm{~s} \\ 31 & 94^{\circ} \mathrm{C}-45 \mathrm{~s} & 55^{\circ} \mathrm{C}-45 \mathrm{~s} & 72^{\circ} \mathrm{C}-45 \mathrm{~s} \\ 1 & 94^{\circ} \mathrm{C}-45 \mathrm{~s} & 55^{\circ} \mathrm{C}-45 \mathrm{~s} & 72^{\circ} \mathrm{C}-10 \text { min }\end{array}$

(b) AS-PCR

\begin{tabular}{llll}
1 & $97^{\circ} \mathrm{C}-2 \mathrm{~min}$ & $55.8^{\circ} \mathrm{C}-45 \mathrm{~s}$ & $72^{\circ} \mathrm{C}-1.5 \mathrm{~min}$ \\
29 & $94^{\circ} \mathrm{C}-45 \mathrm{~s}$ & $55.8^{\circ} \mathrm{C}-45 \mathrm{~s}$ & $72^{\circ} \mathrm{C}-1.5 \mathrm{~min}+4 \mathrm{~s}$ each \\
1 & $94^{\circ} \mathrm{C}-45 \mathrm{~s}$ & $55.8^{\circ} \mathrm{C}-45 \mathrm{~s}$ & $72^{\circ} \mathrm{C}-10 \mathrm{~min}$ \\
\hline
\end{tabular}

4 
1 Table 3

2 Variants of the goat CSN1S1 gene

3

\begin{tabular}{|c|c|c|c|c|c|c|c|c|}
\hline \multirow{2}{*}{$\begin{array}{l}\text { CSN1S1 } \\
\text { alleles }\end{array}$} & \multicolumn{8}{|c|}{ Nucleotide and amino acid position } \\
\hline & $\begin{array}{l}\text { 16th/17th nt } \\
\text { (3rd exon) }\end{array}$ & $\begin{array}{l}8 \text { th nt (4th } \\
\text { exon) }\end{array}$ & $\begin{array}{l}\text { 23th nt (9th } \\
\text { exon) }\end{array}$ & $\begin{array}{l}\text { 22th nt (10th } \\
\text { exon) }\end{array}$ & $\begin{array}{l}\text { 14th nt (12th } \\
\text { exon) }\end{array}$ & $\begin{array}{l}\text { 139th nt } \\
\text { (17th exon) }\end{array}$ & $\begin{array}{l}\text { From 181th nt } \\
\text { (12th intron) }\end{array}$ & $\begin{array}{l}\text { Between 124th and } \\
125 \text { th nt (19th exon) }\end{array}$ \\
\hline B1 & $\mathrm{CA} \mathrm{His}^{8}$ & T Leu $^{16}$ & $\mathrm{CSer}^{66}$ & $\mathrm{G} \mathrm{Glu}^{77}$ & G Arg ${ }^{100}$ & A $\mathrm{Thr}^{196}$ & & \\
\hline $\mathrm{B} 2 *$ & & $\mathrm{C} \operatorname{Pro}^{16}$ & & & & & & \\
\hline B3 & & C Pro ${ }^{16}$ & & & A Lys ${ }^{100}$ & & & \\
\hline B4 & & C Pro ${ }^{16}$ & & & A Lys ${ }^{100}$ & G Ala $^{196}$ & & \\
\hline $\mathrm{C}$ & $\mathrm{AT} \mathrm{Ile}^{8}$ & C Pro ${ }^{16}$ & & & A Lys ${ }^{100}$ & $\mathrm{G} \mathrm{Ala}^{196}$ & & \\
\hline $\mathrm{A}^{*}$ & & & & $\mathrm{C} \mathrm{Gln}{ }^{77}$ & & & & \\
\hline $\mathrm{F}$ & & C Pro ${ }^{16}$ & Deleted & & & & & \\
\hline $\mathrm{N}$ & & & Deleted & $\mathrm{C} \mathrm{Gln}{ }^{77}$ & & & & \\
\hline M & & C Pro ${ }^{16}$ & T Leu $^{66}$ & $\mathrm{C} \mathrm{Gln}{ }^{77}$ & & & & \\
\hline $\mathrm{E}$ & & C Pro ${ }^{16}$ & & & A Lys ${ }^{100}$ & $\mathrm{G} \mathrm{Ala}^{196}$ & & Insertion LINE \\
\hline 01 & & & & $\mathrm{C} \mathrm{Gln}{ }^{77}$ & & Deleted & Deletion $\sim 8.5 \mathrm{~kb}$ & Deleted \\
\hline
\end{tabular}

4
5

6 The CSN1S1 B1 allele is the original one from which the different alleles originate.

7 Nucleotides present at polymorphic positions and corresponding amino acid changes in

8 each variant are indicated. Nucleotides and amino acid positions in the protein are also 9 indicated. CSN1S1 A* = A, G, I, H, 02; CSN1S1 B2* = B2, L. 
$1 \quad$ Table 4

2 Number of individuals typed (no.), observed genotypes and allele frequencies at CSNISI

3 locus in the local Neapolitan goat

\begin{tabular}{|c|c|c|}
\hline Observed genotypes & No. & \\
\hline $\mathrm{A}^{*} \mathrm{~A}^{*}$ & 6 & \\
\hline A*B3 & 11 & \\
\hline A*B4 & 2 & \\
\hline $\mathrm{A}^{*} \mathrm{C}$ & 2 & \\
\hline$A^{*} E$ & 2 & \\
\hline$A^{*} \mathrm{~F}$ & 34 & \\
\hline$A^{*} N$ & 18 & \\
\hline B1F & 4 & \\
\hline $\mathrm{B} 2 * \mathrm{E}$ & 2 & \\
\hline $\mathrm{B} 2 * \mathrm{~F}$ & 2 & \\
\hline $\mathrm{B} 2 * \mathrm{~N}$ & 2 & \\
\hline B3B3 & 2 & \\
\hline B3B4 & 2 & \\
\hline B3E & 2 & \\
\hline B3F & 18 & \\
\hline B3N & 4 & \\
\hline B4B4 & 11 & \\
\hline B4E & 2 & \\
\hline B4F & 18 & \\
\hline $\mathrm{B} 4 \mathrm{~N}$ & 4 & \\
\hline $\mathrm{EE}$ & 4 & \\
\hline $\mathrm{EF}$ & 16 & \\
\hline $\mathrm{EN}$ & 15 & \\
\hline FF & 34 & \\
\hline FN & 50 & \\
\hline $\mathrm{NN}$ & 18 & \\
\hline Total & 285 & \\
\hline CSN1S1 alleles & Frequency & Genotyping \\
\hline B1 & 0.007 & MnlI PCR-RFLPa \\
\hline $\mathrm{B} 2 *$ & 0.012 & $M n l$ I PCR-RFLPa \\
\hline B3 & 0.072 & DedI PCR-RFLPa \\
\hline B4 & 0.085 & AS-PCR ${ }^{a}$ \\
\hline $\mathrm{C}$ & 0.004 & $H p h \mathrm{I}$ PCR-RFLP ${ }^{\mathrm{a}}$ \\
\hline$A^{*}$ & 0.142 & $X m n \mathrm{I}$ PCR-RFLP ${ }^{\mathrm{b}}$ \\
\hline M & - & $\mathrm{ACRS}^{\mathrm{c}}$ \\
\hline $\mathrm{E}$ & 0.083 & $\mathrm{PCR}^{\mathrm{d}}$ \\
\hline $\mathrm{F}$ & 0.368 & $X m n I$ PCR-RFLP ${ }^{b}$ \\
\hline $\mathrm{N}$ & 0.227 & $X m n I$ PCR-RFLP ${ }^{b}$ \\
\hline 01 & - & AS-PCR ${ }^{\mathrm{e}}$ \\
\hline
\end{tabular}

CSN1S1 A* = A, G, I, H, 02; CSN1S1 B2* = B2, L.

a Present work.

${ }^{\text {b }}$ Ramunno et al. (2000).

c Bevilacqua et al. (2002).

d Jansà Pérez et al. (1994).

e Cosenza et al. (2003). 


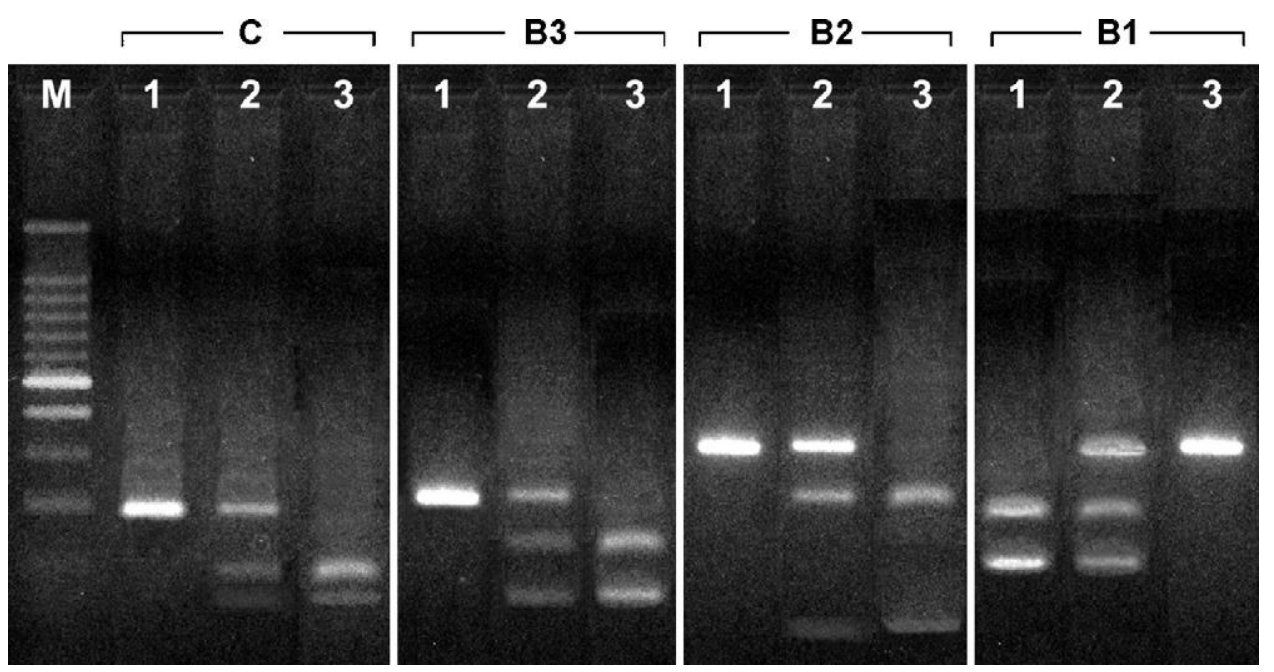

3 Fig. 1. Typing of CSN1S1 B1, B2*, B3, C alleles by PCR-RFLP performed by going 4 backwards along the phylogenetic tree. Lines 1 and 3 are homozygous samples for 5 CSN1S1 C, B3, B2*, B1 and CSN1S1 "non-C", "non-B3", "non-B2*", "non-B1", alleles, 6 respectively. Lines 2 are heterozygous samples, $\mathrm{M}$ is a 100 bp ladder (Promega). CSNIS1 $7 \quad \mathrm{~B} 2 *=\mathrm{B} 2$, L. 


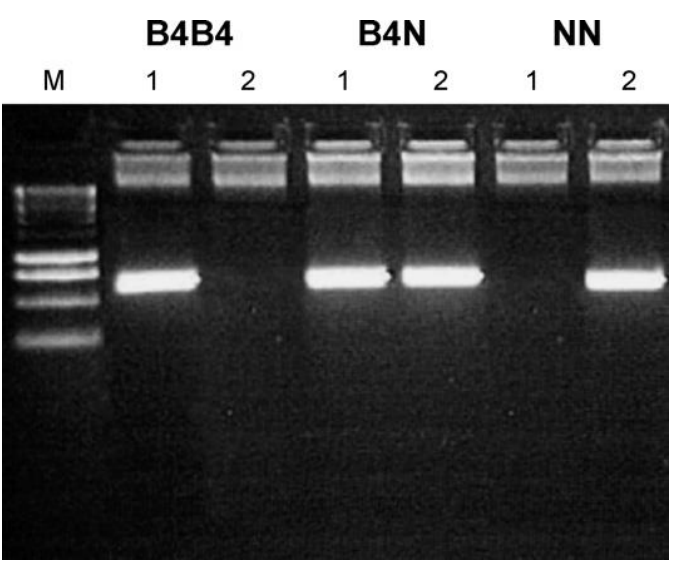

2 Fig. 2. Typing of CSN1S1 B4 allele by AS-PCR. Lines 1 are amplicons obtained with a 3 specific forward primer for CSN1S1 B4 allele, lines 2 are products obtained with a specific 4 forward primer for not CSN1S1 B4 allele, M is a 100 bp molecular ladder (Promega). 5 CSN1S1 N = "non- B4" allele. 


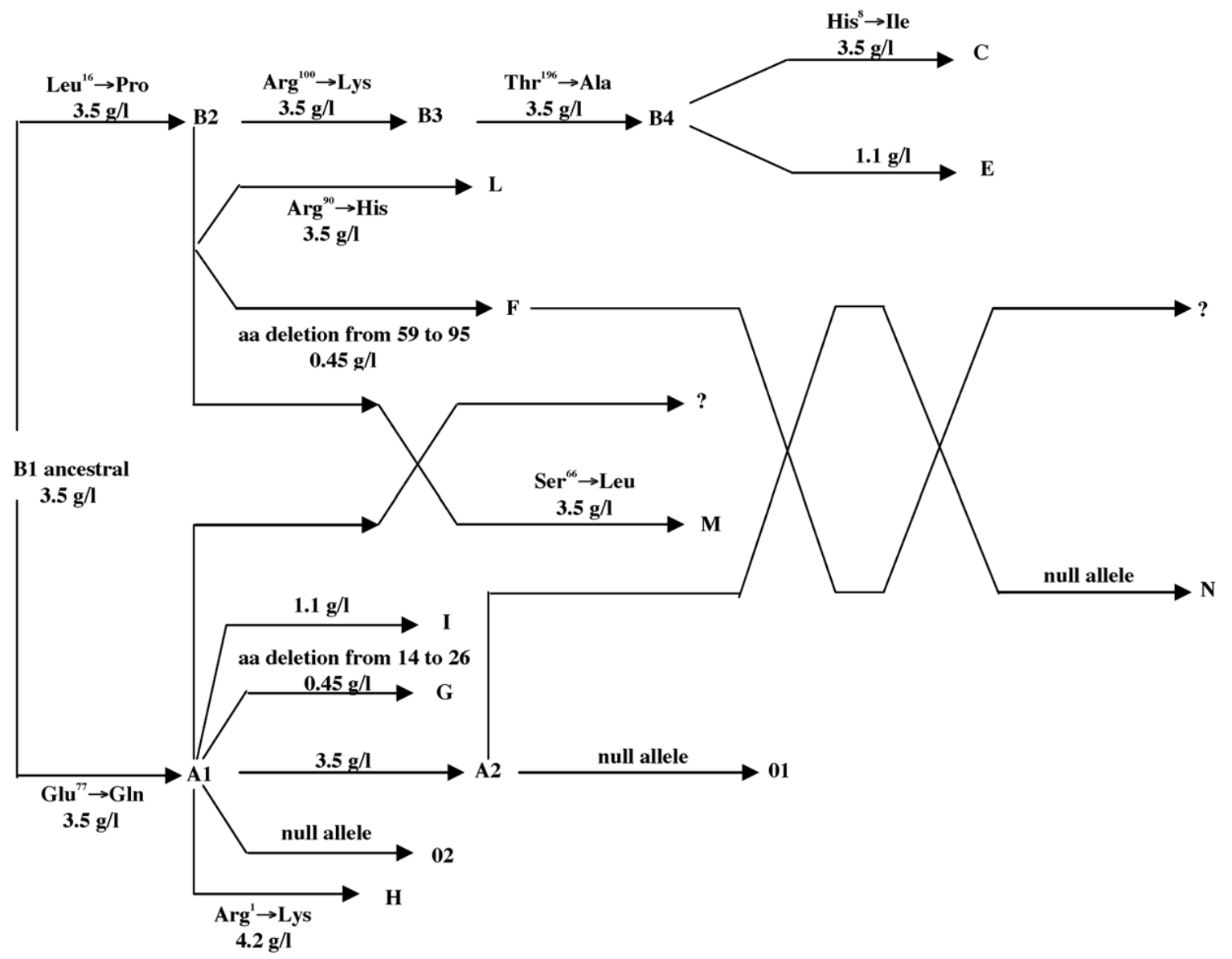

2 Fig. 3. Phylogeny tree for the goat CSN1S1 alleles and differences between the 3 corresponding variants. The new proposed phylogeny with respect to those proposed by 4 Chianese et al. (1997) and Bevilacqua et al. (2002), has been enriched with two novel 5 variants (N and A2) reported in Ramunno et al. (2005). The as1-casein content in milk 6 and the aminoacid differences between variants are also indicated for each variant. The 7 nucleotide mutations are indicated in the text except for I and 02 which are as yet 8 uncharacterized. 